\title{
Diel and Seasonal Occurrence Patterns of Drifting Fish Larvae in the Teima Stream, Okinawa Island ${ }^{1}$
}

\author{
Ken Maeda ${ }^{2,3}$ and Katsunori Tachibara ${ }^{2}$
}

\begin{abstract}
Drifting fish larvae were collected with a plankton net in the lower reaches of a freshwater area of the Teima Stream, Okinawa Island, Japan, during $24 \mathrm{hr}$ periods each month from June 1998 to October 1999 (except July 1998). Newly hatched larvae of several gobioid and two pipefish species were collected, and their morphology was described. The larval occurrences suggested that most species spawn mainly from spring to fall, with some Rhinogobius species spawning in winter. Larvae of all fishes occurred predominantly during hours after dusk throughout the year. It is suggested that larvae of amphidromous fishes spawned in freshwater streams on Okinawa Island begin to drift soon after hatching at dusk and complete their exit from freshwater areas into the estuary and sea by midnight.
\end{abstract}

Amphidromous fishes frequently dominate the freshwater fish fauna of insular streams (Donaldson and Myers 2002, Fitzsimons et al. 2002, Keith 2003). After freshwater spawning, hatched larvae migrate downstream to the sea, where they grow as pelagic larvae before returning to freshwater for further growth and reproduction (Myers 1949, McDowall 1997). Thus, the migration starts when the newly hatched larvae leave the spawning nest and drift with the stream flow. Some reports have discussed the mechanism of their downstream migration (Iguchi and Mizuno 1991, Takahashi and Niimi 1998, Bell 2007, Iguchi 2007), but the process of the larval downstream migration has not been fully understood due to a lack of detailed study about the occurrence of the drifting larvae.

${ }^{1}$ This study was partially supported by the 21 st Century Center of Excellence (COE) Program of the University of the Ryukyus. Manuscript accepted 19 April 2009.

${ }^{2}$ Faculty of Science, University of the Ryukyus, 1 Senbaru, Nishihara-cho, Nakagami-gun, Okinawa 9030213, Japan.

${ }^{3}$ Corresponding author (e-mail: goby@live.jp).

Pacific Science (2010), vol. 64, no. 2:161-176

doi: $10.2984 / 64.2 .161$

(C) 2010 by University of Hawai'i Press

All rights reserved
Okinawa is the largest island in the Ryukyu Archipelago, located in the western $\mathrm{Pa}$ cific. The freshwater fish fauna of Okinawa Island includes a few resident species that inhabit freshwater throughout life and many diadromous and peripheral species that migrate or move between freshwater and the sea. For example, of the 35 species recorded in the freshwater area of Teima Stream, Okinawa Island, six are residents (four families, including Cyprinidae and introduced Cichlidae), four are catadromous (adults spawn at sea, juveniles grow in freshwater: Anguillidae and Kuhlidae), 15 are amphidromous (Syngnathidae, Eleotridae, and Gobiidae), and three are quasi-amphidromous (the migration pattern between stream and sea is common with amphidromous fishes, but quasiamphidromous fishes spawn in both fresh and brackish waters: Syngnathidae, Eleotridae, and Gobiidae). Seven are peripheral (marine spawners that enter freshwater optionally: seven families, including Mugilidae and Carangidae) (Maeda and Tachihara 2006). Of these, amphidromous and quasiamphidromous species spawn in freshwater, and the newly hatched larvae then drift downstream.

We collected drifting fish larvae with a plankton net in the lower reaches of the freshwater area of Teima Stream and examined larval morphology, spawning season, and the process of downstream migration in 
terms of diel and seasonal larval occurrence patterns.

\section{MATERIALS AND METHODS}

Teima Stream, on the east coast of the northern part of Okinawa Island, southern Japan $\left(26^{\circ} 33-35^{\prime} \mathrm{N}, 128^{\circ} 04-06^{\prime} \mathrm{E}\right)$, is about 6.7 $\mathrm{km}$ long and flows into Oh-ura Bay (Figure 1). Tidal fluctuations and saline water have been observed up to $2.0 \mathrm{~km}$ from the stream mouth (Maeda and Tachihara 2004). We conducted larval samplings in freshwater about $0.1 \mathrm{~km}$ above the upper limit of the tidally influenced area (i.e., $2.1 \mathrm{~km}$ from the stream mouth) (Figure 1). The substratum at the sampling site was gravel and pebbles. Bank vegetation included the reed Phragmites karka, spiderwort Commelina diffusa, and umbrella plant Cyperus alternifolius. An artificial perpendicular step (50-80 cm high) without a fishway was located about $0.2 \mathrm{~km}$ upstream of the site, and the distribution of some fishes, including Microphis leiaspis, Eleotris acanthopoma, and Redigobius bikolanus, was restricted to the reaches below this step (Maeda and Tachihara 2006).

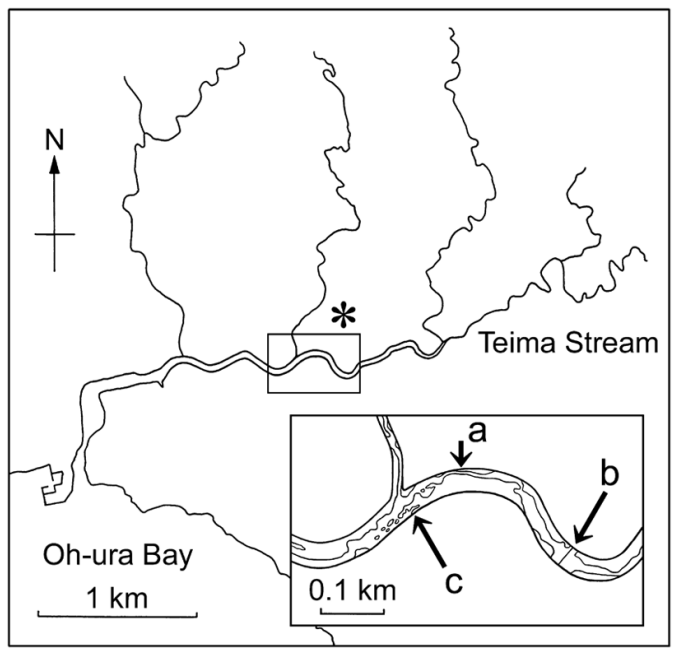

Figure 1. Map showing the sampling site in Teima Stream, Okinawa Island. Asterisk indicates location of map detail. $a$, sampling site; $b$, artificial perpendicular step; $c$, upper limit of tidally influenced area.
Larvae were collected with a plankton net (Kitahara-type, mouth diameter $23 \mathrm{~cm}$, length $85 \mathrm{~cm}$, mesh XX-13) set at the center of the stream flow for $24 \mathrm{hr}$ per month from June 1998 to October 1999 (except July 1998). Water depth and stream width at the site were $27-37 \mathrm{~cm}$ and $200-520 \mathrm{~cm}$, respectively. All materials collected were extracted from the net after each $1 \mathrm{hr}$ sampling period and fixed in 5\% formalin. Collecting started at 1300 hours in June and September 1998, 0900 hours in August 1998, and 1200 hours from October 1998 to October 1999. Water temperature and intensity of illumination around the net were measured every hour during the samplings, with an alcohol thermometer and illuminometer (SLX-1332, Sansyo, Tokyo, Japan).

Larvae were sorted from $10 \%$ of the entire collection under a stereomicroscope in the laboratory with the following steps: (1) all materials collected during each $1 \mathrm{hr}$ period were diluted with water to $500 \mathrm{ml}$ and stirred; (2) $2 \mathrm{ml}$ samples were pipetted 25 times from the $500 \mathrm{ml}$ diluted material; (3) larvae were removed from each of the 25 samples (total $50 \mathrm{ml}$ ) and counted. Number of whole larval individuals collected during each $1 \mathrm{hr}$ period was estimated from the number of larvae in the $50 \mathrm{ml}$ sample multiplied by 10 . But larval counts for some $1 \mathrm{hr}$ samples in June 1998 were made by counting all larvae in the entire collection. We measured the notochord length (NL) of all sorted, unbroken larvae of pipefishes and $R$. bikolanus and 40-46 larvae of other species randomly selected from samples taken in the 1700-2200 hours period.

To compare larval abundance between months with different water conditions, larval abundances were standardized from October 1998 to October 1999 by the following procedure: During five trials, 100 floating granules (diameter 1.0-1.5 $\mathrm{mm}$ ) were released $10 \mathrm{~m}$ upstream from a net before larval sampling started; five trials were also conducted after larval sampling was completed (in total, 1,000 granules were released per sampling event). The filtration efficiency of the net (number of granules collected in the net/ $1,000)$ was calculated for each sampling event. Larval abundances were expressed as the esti- 
mated number of larvae that passed through the sampling site during $24 \mathrm{hr}$ (number of larvae collected/filtration efficiency).

\section{RESULTS}

\section{Larval Descriptions}

Gobioid and pipefish larvae were collected. Most larvae had a yolk sac and were considered to be at the newly hatched stage (Figures $2,3)$. Gobioid larvae were sorted into a small undeveloped type, without pigmented eyes, mouth, or pectoral fins $(<1.70 \mathrm{~mm}$ NL [Figure $2 a, b])$, and others $(>1.80 \mathrm{~mm}$ [Figure $2 c-f])$. The latter were further identified as Redigobius bikolanus, Rbinogobius giurinus, or other Rhinogobius spp. Pipefish larvae were identified as Microphis leiaspis or Microphis brachyurus.

Small undeveloped type larvae were $0.82-$ $1.60 \mathrm{~mm}$ NL (mean $1.29 \mathrm{~mm}, n=46$ [Figure 4]), with a large yolk sac (mean diameter 0.31 $\mathrm{mm}$ ) and without pigmented eyes, mouth, or pectoral fins (Figure 2a,b). Although pigment patterns varied, most larvae had melanophores around the snout, on anterior and posterior parts of the yolk sac, and ventrally on the trunk and the tail.

Redigobius bikolanus larvae were 1.82-2.26 mm NL (mean $2.01 \mathrm{~mm}, n=30$ [Figure 4]), with a yolk sac (mean diameter $0.22 \mathrm{~mm}$ ), pigmented eyes, mouth, and pectoral fins (Figure 2c), and had two characteristic large melanophores ventrally on the trunk and the tail. Melanophores also occurred around the upper and lower jaws, around the tip of the snout, at the angles of the lower jaws (below the eyes), ceiling of the oral cavity, ventrally on and posterior to the otic capsule, dorsally on the gas bladder and yolk sac, and ventrally on the abdomen.

Rbinogobius giurinus larvae were smaller (2.23-2.70 $\mathrm{mm} \mathrm{NL}$, mean $2.39 \mathrm{~mm}, n=41$ ) than their congeners (Figure 4). The majority had a yolk sac (mean diameter $0.15 \mathrm{~mm}$ ), developed mouth, and pectoral fins (Figure 2e), but a few undeveloped larvae caught at dawn and in daytime had a large yolk sac (diameter $0.30 \mathrm{~mm}$ ), undeveloped mouth, smaller gas bladder, and smaller pectoral fins (Figure
$2 d$ ). The larvae had two conspicuous dorsal melanophores, one on the trunk and the other on the midtail, as well as two conspicuous ventral melanophores located below those, which were expanded more widely than the dorsal melanophores. The anterior ventral melanophore was expanded posteriorly beyond the anus. Melanophores also occurred at the angles of the lower jaws (below the eyes), dorsally on the gas bladder and the yolk sac, ventrally on the abdomen, and ventrally on the posterior part of the tail.

Rhinogobius spp. larvae (except $R$. giurinus) were the largest of the gobioid drifting larvae (3.43-3.90 mm, mean $3.70 \mathrm{~mm}, n=40$ [Figure 4]); these usually had a yolk sac (mean diameter $0.21 \mathrm{~mm}$ ), pigmented eyes, mouth, and pectoral fins. One dorsal melanophore occurred on the midtail (Figure $2 f$ ) but none dorsally on the trunk. Melanophores also occurred ventrally on the posterior part of the trunk and on the tail, dorsally on the gas bladder, and ventrally on the abdomen.

Pipefish larvae were larger than gobioid larvae. Microphis leiaspis larvae were 4.22$5.28 \mathrm{~mm}$ NL (mean $4.85 \mathrm{~mm}, n=11$ [Figure 4]), with 49-52 myomeres. The majority had a somewhat projected snout (Figure $3 b$ ), but one undeveloped larva (4.22 $\mathrm{mm} \mathrm{NL}$ ) had a rounded snout, smaller pectoral fins, and a larger yolk sac (Figure 3a). Scattered melanophores dotted the body and sometimes formed saddlelike shapes dorsally.

Microphis brachyurus larvae were 4.10-4.46 $\mathrm{mm} \mathrm{NL}$ (mean $4.32 \mathrm{~mm}, n=3$ [Figure 4]). The number of myomeres (42 and 45 on two specimens) was the only character that distinguished these larvae from $M$. leiaspis. Although the total number of myomeres of one specimen could not be counted because of its damaged trunk, it was identified to this species based on the number of myomeres in the tail. The larvae had a large yolk sac and a relatively round snout (Figure $3 c$ ). Scattered melanophores dotted the body.

\section{Occurrences}

The monthly changes of water temperature and larval abundance are shown in Figure 5. The most abundant were the small 

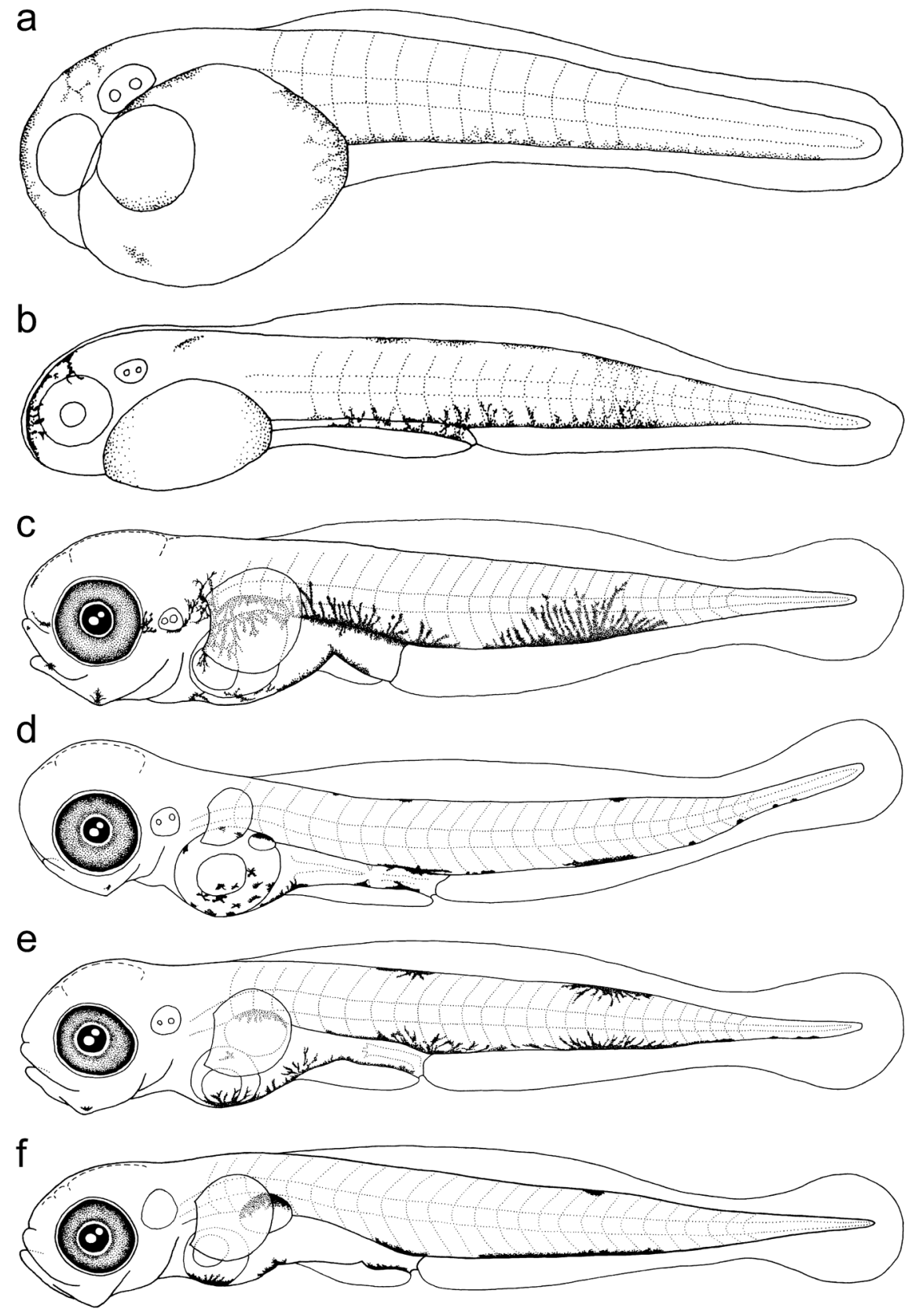

Figure 2. Drifting gobioid larvae collected at the freshwater sampling site of Teima Stream: $a$, small undeveloped type collected in September 1999 (0.89 mm notochord length [NL]); $b$, small undeveloped type collected in September 1999 (1.37 mm NL); c, Redigobius bikolanus collected in September 1999 (1.92 mm NL); d, Rhinogobius giurinus collected in August 1999 (2.24 mm NL); e, Rbinogobius giurinus collected in October 1999 (2.26 mm NL); $f$, unidentified Rhinogobius sp. collected in March 1999 (3.82 mm NL). 


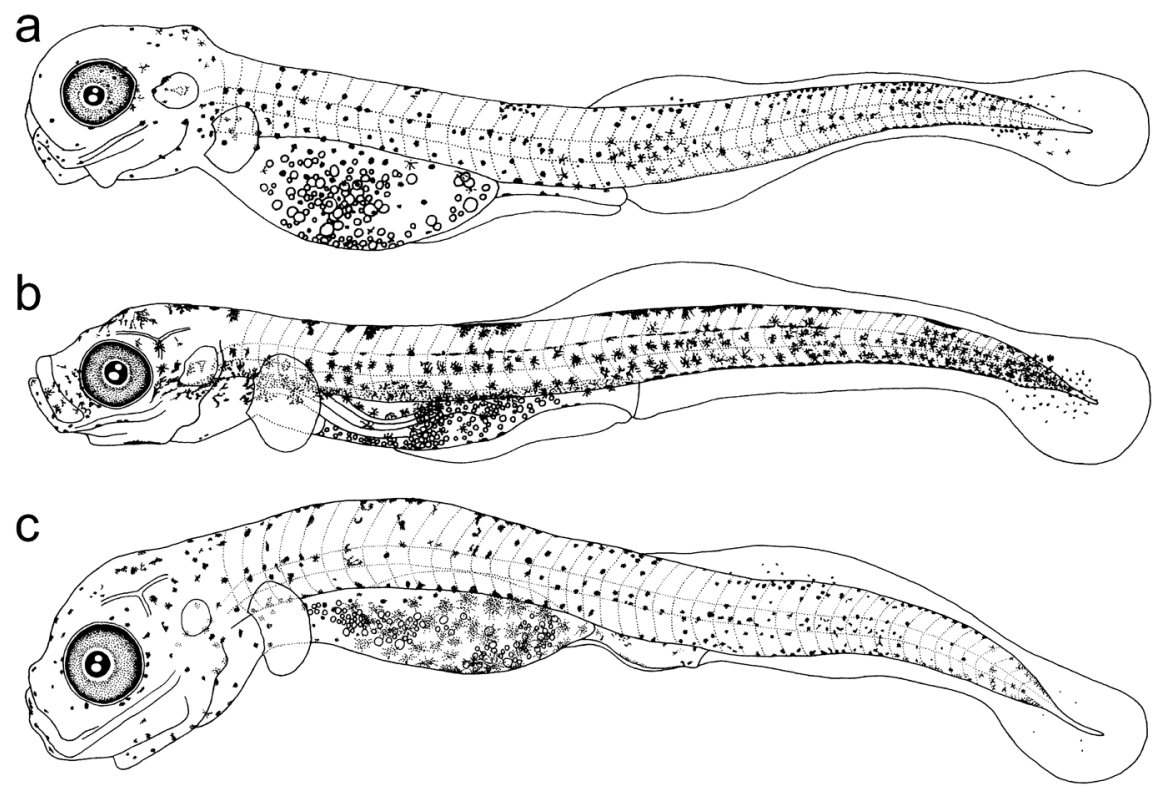

FIgURE 3. Drifting pipefish larvae collected at the freshwater sampling site of Teima Stream: a, Microphis leiaspis collected in August 1998 (4.22 mm in notochord length [NL]); b, Microphis leiaspis collected in August 1998 (4.80 mm NL); c, Microphis brachyurus collected in December 1998 (4.10 mm NL).

undeveloped type, occurring from October 1998 to January 1999 and from May to October 1999, although the abundance in January was very small. The seasonal occurrence of $R$. bikolanus was similar to that of the small undeveloped type, with occurrences of both apparently restricted to warmer temperatures $\left(\geq 20^{\circ} \mathrm{C}\right)$. Rhinogobius giurinus occurred throughout most of the year but was relatively less abundant during winter (November 1998-April 1999). The other Rhinogobius spp. occurred from December 1998 to June 1999 , and their abundance in winter was notable. The two pipefish species were collected only in 1998.

Diel occurrence patterns were similar for all species in all months surveyed (Figures 6, $7,8,9,10$, and 11). Most larvae occurred predominantly some hours after dusk, when the intensity of illumination dropped to near 0 lux. Peaks occurred just after nightfall, and the larvae gradually decreased later in the night. Few larvae occurred in daytime, and nocturnal occurrences after midnight were also few.

\section{DISCUSSION}

\section{Identifications}

Morphologies of the small undeveloped type larvae varied, but we could not identify them definitively. They most likely comprised Eleotris acanthopoma, Eleotris fusca, Sicyopterus japonicus, Stiphodon percnopterygionus, Stenogobius sp., and Awaous melanocephalus, because only these fishes among those found in the upper reaches of the sampling site are known to hatch in such undeveloped stages (Dôtu and Mito 1955, Yamasaki and Tachihara 2006, 2007, Maeda et al. 2008; our unpubl. data).

The morphology of Rhinogobius giurinus larvae was unique, and they could be distinguished from their congeners. Three other Rbinogobius species (these three species are tentatively called Rbinogobius sp. CB, Rbinogobius sp. MO, and Rhinogobius sp. DA, although their taxonomy has not been established [see Akihito et al. 2002]) are abundant in the upper reaches of the sampling site (Maeda and Tachihara 2006) but their larvae could not 

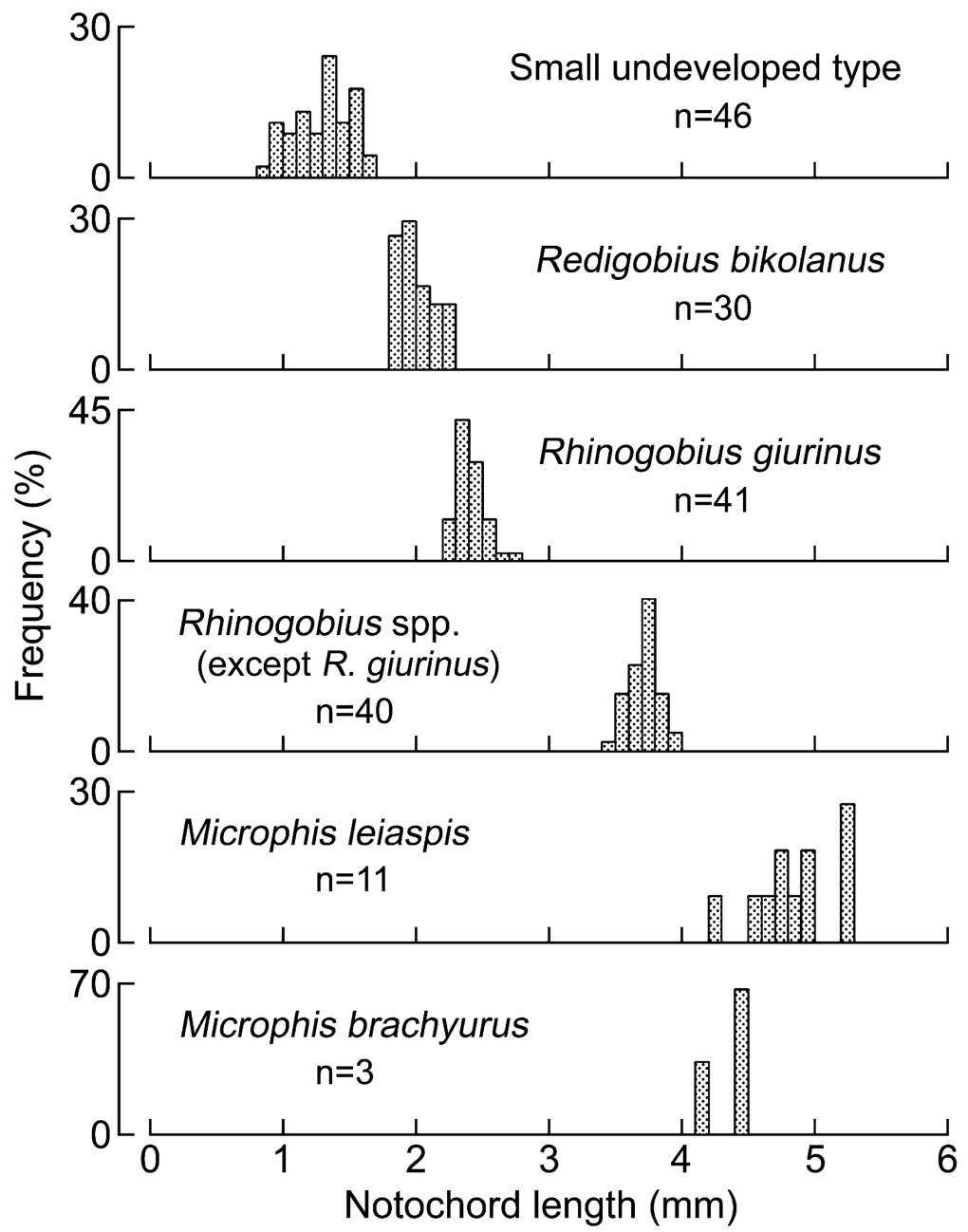

FIGURE 4. Size frequency distributions of drifting larvae collected with a plankton net at the freshwater sampling site of Teima Stream.

be identified to the species level because of their similar larval morphologies.

\section{Spawning Season}

The seasonal occurrence patterns of newly hatched larvae indicate their spawning season in the upper reaches of the sampling site. Of the possible species composing the small undeveloped type, gonadal studies indicate that E. acanthopoma, E. fusca, and S. percnopterygionus spawn from May to December on Oki- nawa Island (Yamasaki and Tachihara 2006, Maeda et al. 2007). This supports our results showing that few of the small undeveloped type larvae occurred from January to April. Although we could not determine speciesspecific spawning seasons, because the larvae could not be identified to the species level, we did find that they scarcely spawn from January to April, when the water temperature is below ca. $20^{\circ} \mathrm{C}$.

Redigobius bikolanus spawning appears to occur from May to December. Rhinogobius 

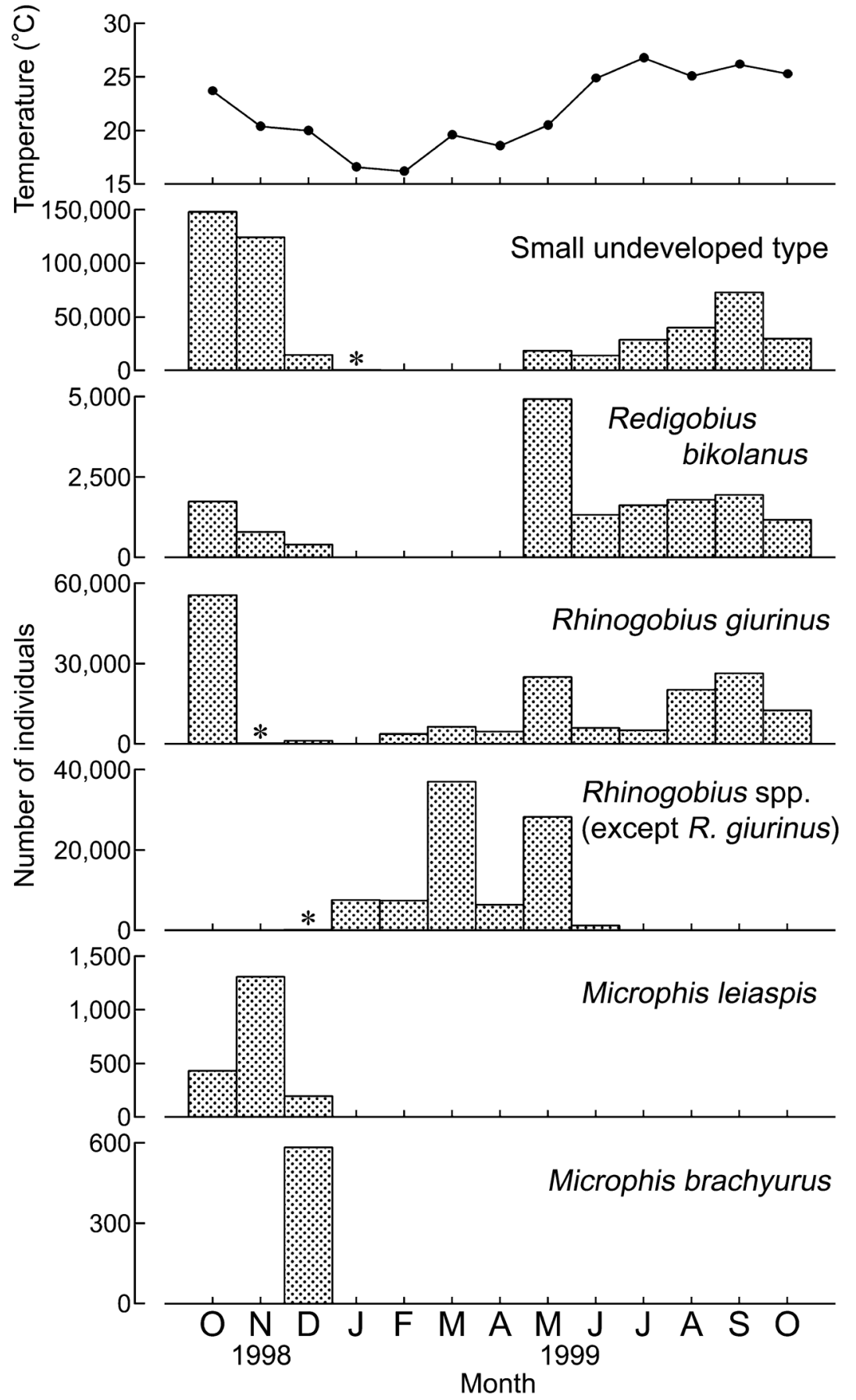

FIGURE 5. Monthly changes in the estimated number of drifting larvae that passed through a freshwater sampling site of Teima Stream during a $24 \mathrm{hr}$ period, and mean water temperature at the site during the $24 \mathrm{hr}$ from October 1998 to October 1999. Asterisks indicate occurrences when few larvae were captured. 


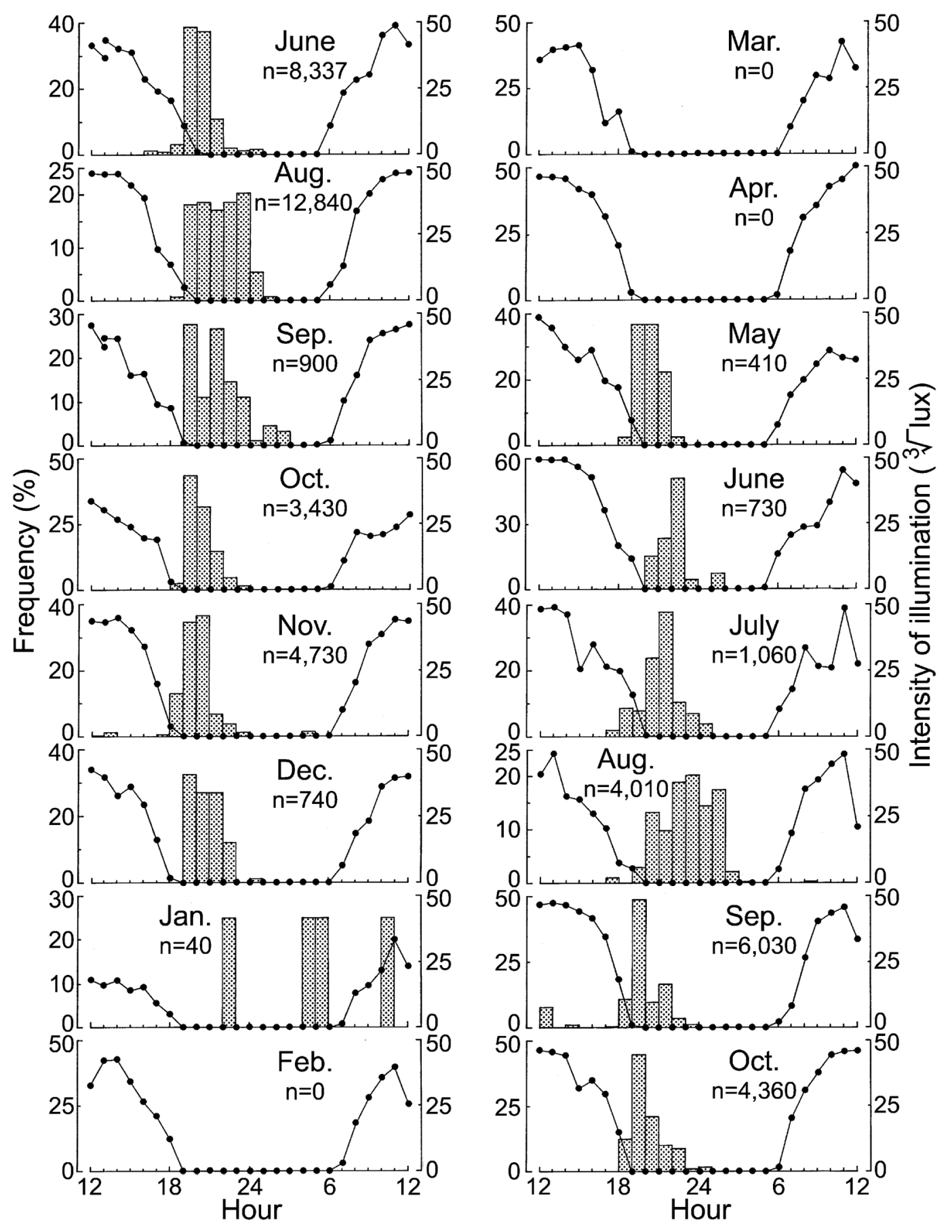

FIGURE 6. Hourly changes in intensity of illumination (solid circles and lines) and frequency of occurrence (bars) of small undeveloped type drifting larvae collected with a plankton net at the freshwater sampling site of Teima Stream from June 1998 to October 1999 (except July 1998). 


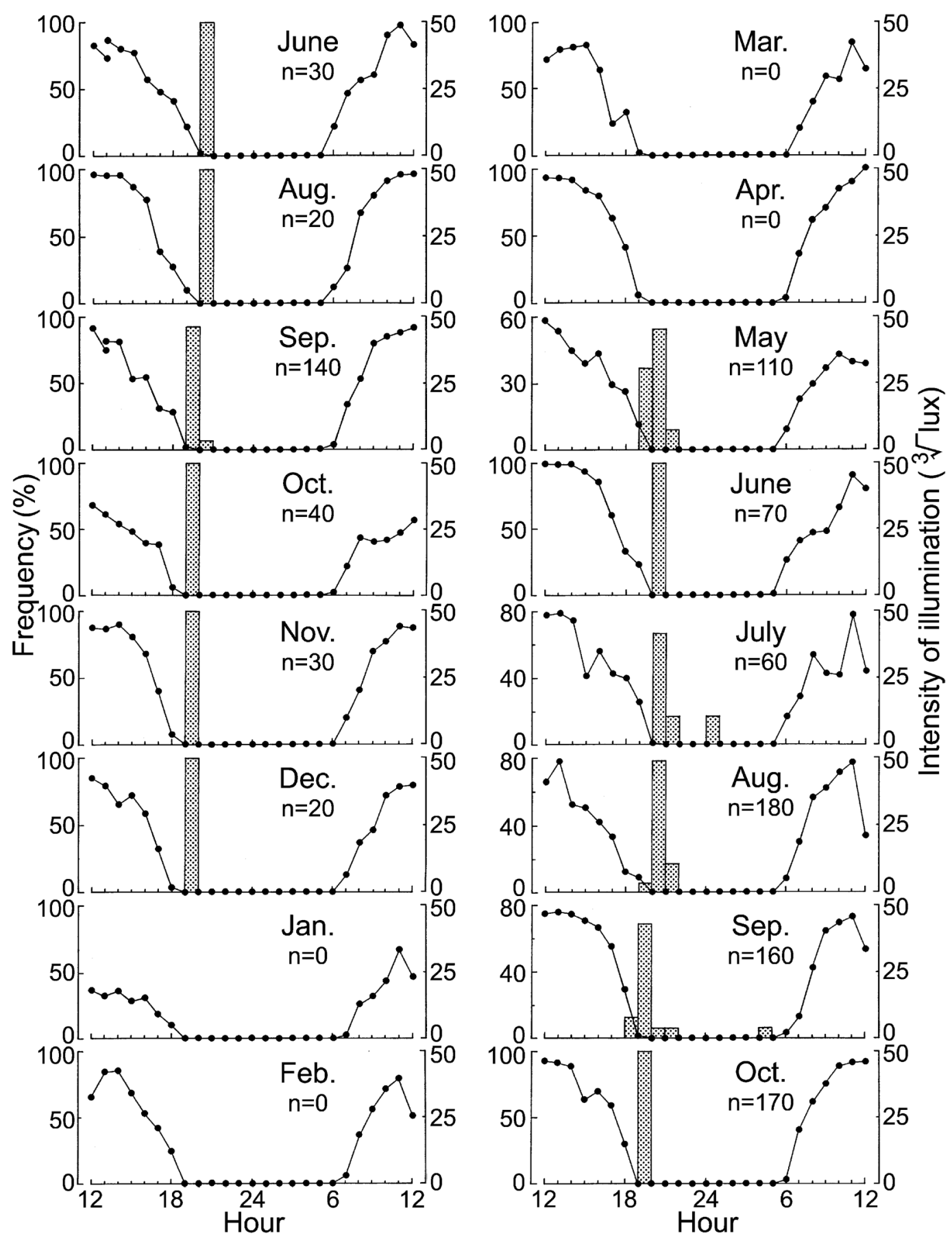

FIgURE 7. Hourly changes in intensity of illumination (solid circles and lines) and frequency of occurrence (bars) of Redigobius bikolanus drifting larvae collected with a plankton net at the freshwater sampling site of Teima Stream from June 1998 to October 1999 (except July 1998). 


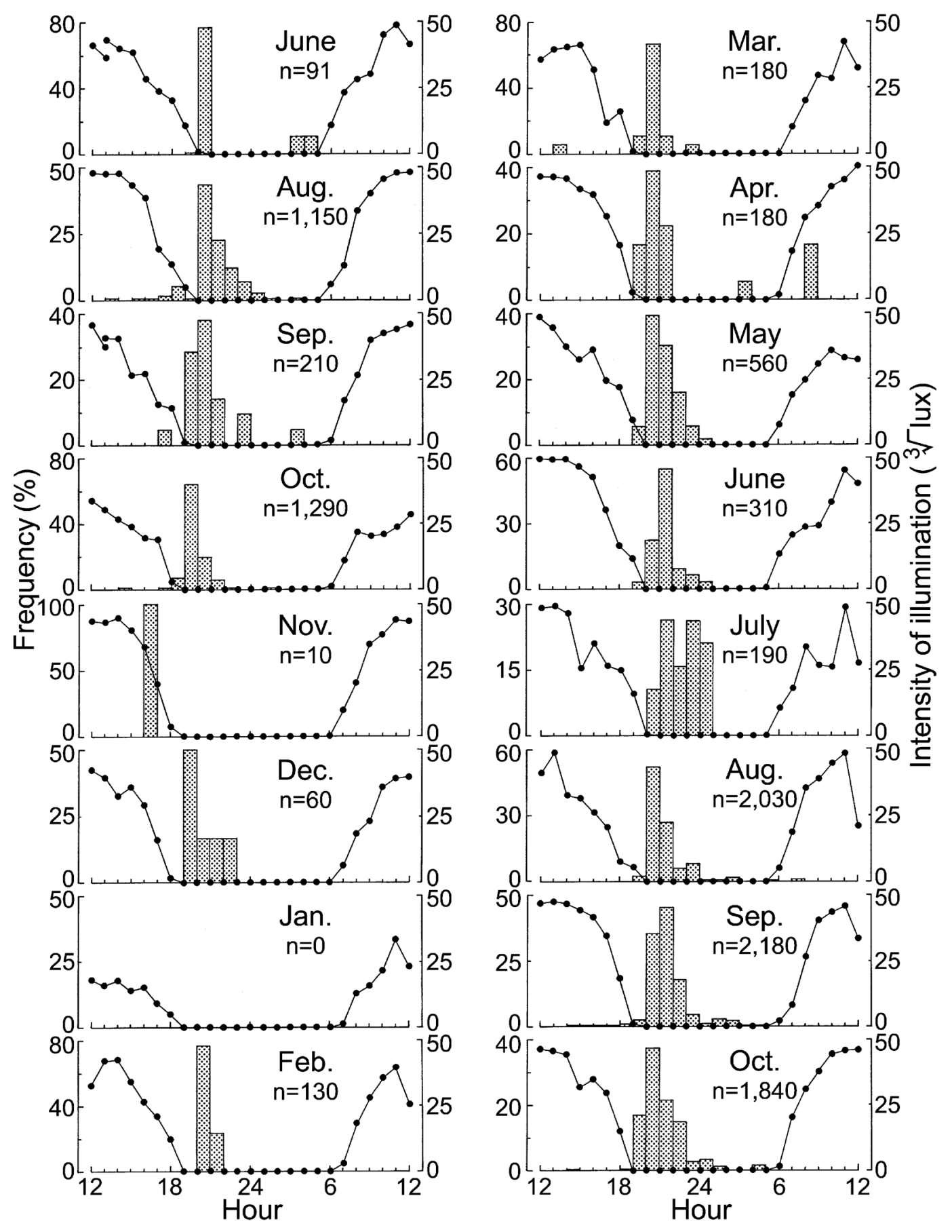

FIGURE 8. Hourly changes in intensity of illumination (solid circles and lines) and frequency of occurrence (bars) of Rhinogobius giurinus drifting larvae collected with a plankton net at the freshwater sampling site of Teima Stream from June 1998 to October 1999 (except July 1998). 


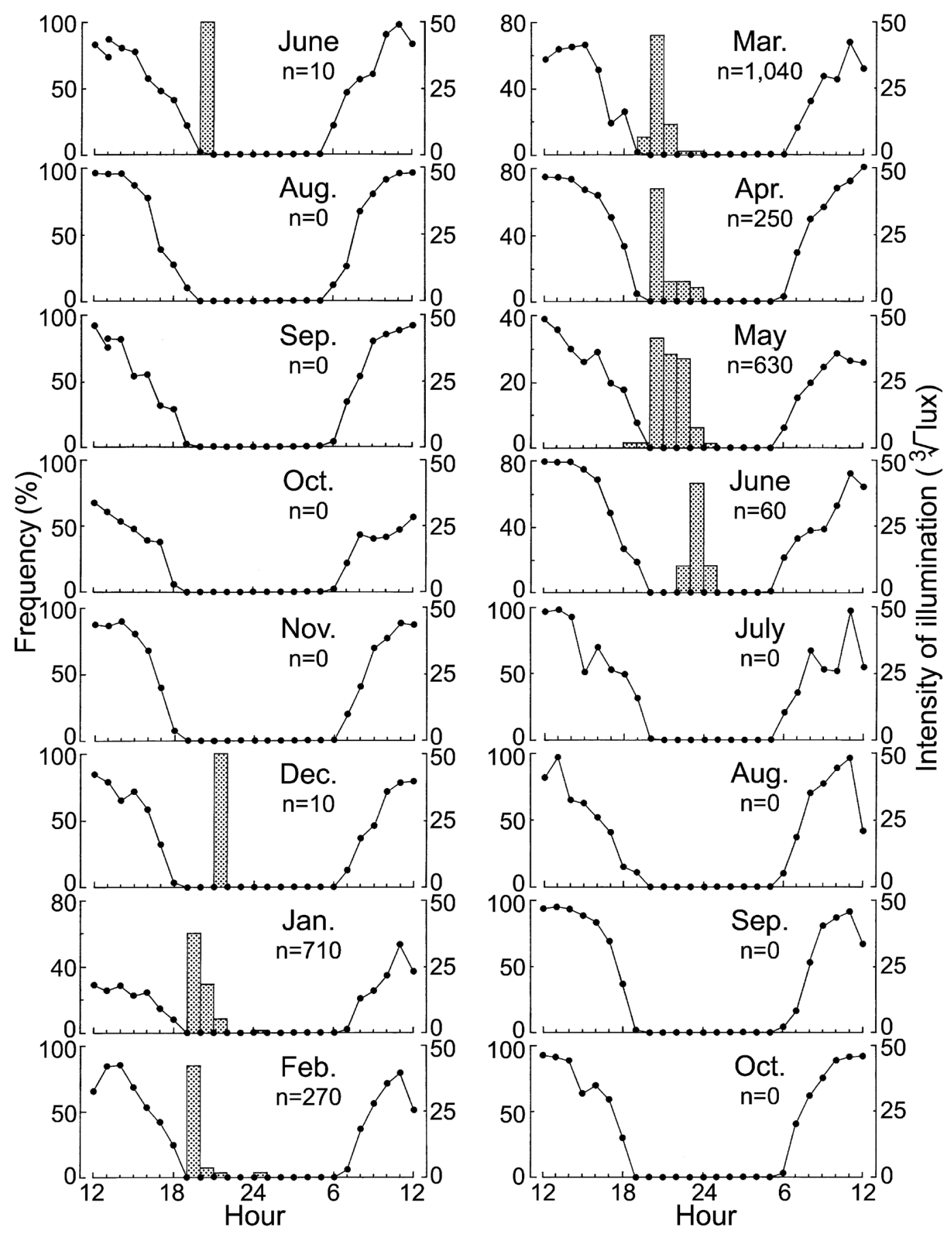

FIGURE 9. Hourly changes in intensity of illumination (solid circles and lines) and frequency of occurrence (bars) of Rhinogobius spp. drifting larvae (except $R$. giurinus) collected with a plankton net at the freshwater sampling site of Teima Stream from June 1998 to October 1999 (except July 1998). 


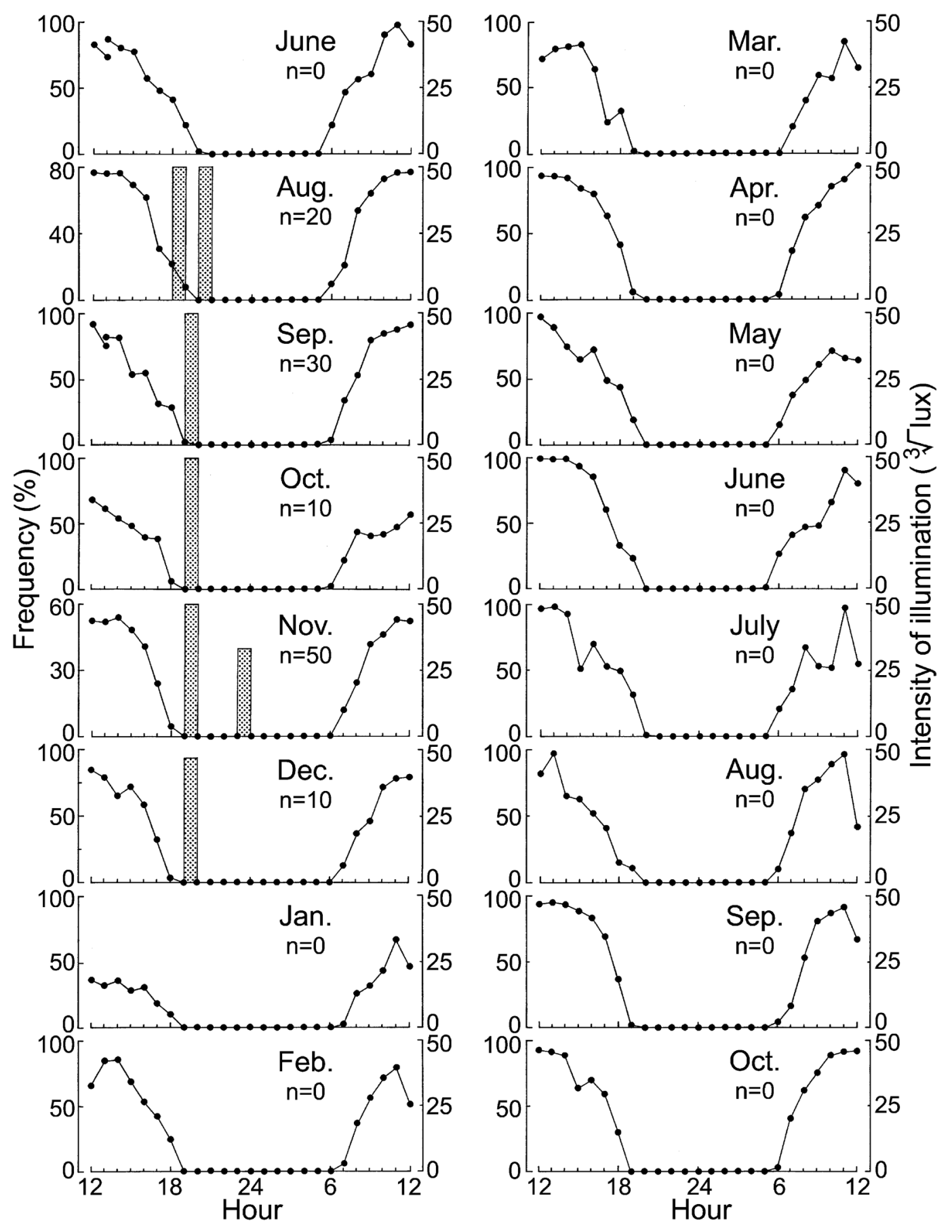

FIGURE 10. Hourly changes in intensity of illumination (solid circles and lines) and frequency of occurrence (bars) of Microphis leiaspis drifting larvae collected with a plankton net at the freshwater sampling site of Teima Stream from June 1998 to October 1999 (except July 1998). 


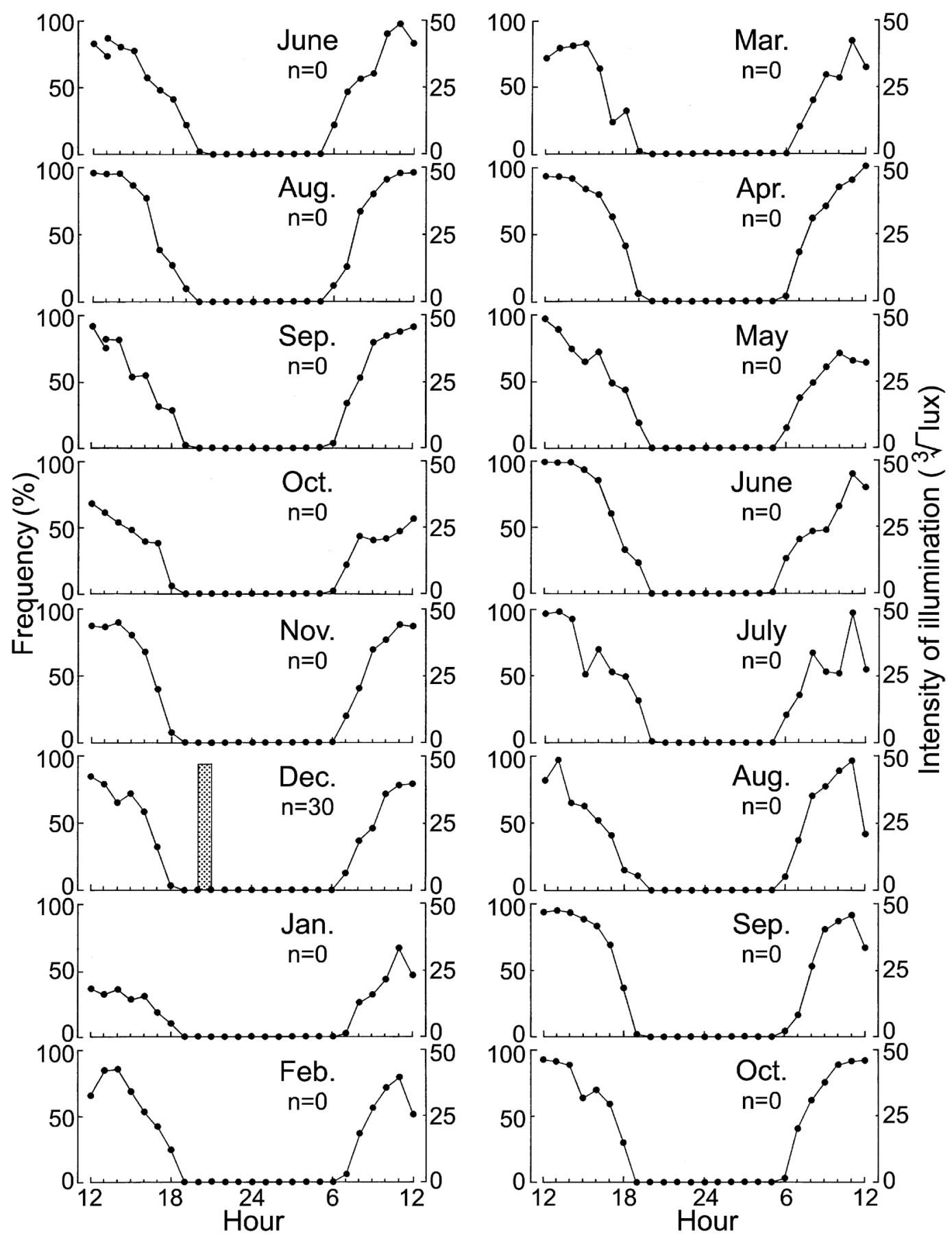

FIGURE 11. Hourly changes in intensity of illumination (solid circles and lines) and frequency of occurrence (bars) of Microphis brachyurus drifting larvae collected with a plankton net at the freshwater sampling site of Teima Stream from June 1998 to October 1999 (except July 1998). 
giurinus may spawn throughout the year, although not vigorously from November to April. The spawning season of other Rhinogobius species was peculiar, in that they spawn from winter to spring. We could not estimate the spawning season of the two pipefishes, owing to the small number of collections.

The number of larvae that passed through the sampling site during a $24 \mathrm{hr}$ period apparently was underestimated for all species. The estimated abundance usually was not more than the number of larvae expected from only one or only a few egg masses in one or a few nests. This underestimation occurred because the $1 \mathrm{hr}$ sampling period was too long to maintain constant filtration efficiency.

\section{Downstream Migration}

Diel occurrence patterns indicated that newly hatched larvae of all species usually drift downstream from dusk to midnight. Diel occurrence patterns of newly hatched amphidromous fish larvae, such as ayu, Plecoglossus altivelis altivelis (Takahashi and Niimi 1998), and some gobioid fishes (Iguchi and Mizuno 1990, Tomiyama et al. 1999, Luton et al. 2005, Bell 2007), are predominately from dusk to midnight, except for tidally influenced areas and steep streams. Downstream migration by pipefish larvae has not been studied. In our study, newly hatched pipefish larvae mainly appeared at dusk. The larvae passively drift downstream, similar to gobioid larvae. Both Microphis leiaspis and Microphis brachyurus hatch at earlier developmental stages than most other pipefishes (Ishihara and Tachihara 2008), and observations of newly hatched $M$. leiaspis larvae under rearing conditions suggest that they are unable to swim against the stream flow (T. Ishihara, pers. comm.).

Iguchi and Mizuno (1991) showed positive phototaxis to 500 lux light and a negative response to light of more than 5,000 lux by newly hatched Rhinogobius sp. larvae and suggested that such phototactic reactions to the temporal change of illumination intensity cause the larval diel occurrence pattern reported in Iguchi and Mizuno (1990). They concluded that larvae leave the nest in re- sponse to the lower light intensity at dusk, with drifting gradually ceasing, owing to the sinking of negatively buoyant larvae at night, larvae halting in the bottom of pools, and rising again at dusk.

However, this explanation may not apply to the small undeveloped type larvae in our study. All small undeveloped type larvae were at an almost uniform newly hatched stage. Their 1-day-old larvae are larger (1.5$1.8 \mathrm{~mm} \mathrm{NL}$ ) and show features distinguishing them from newly hatched larvae (Yamasaki and Tachihara 2006, 2007, Maeda et al. 2008), but we did not find these older larvae. Thus, all larvae we observed probably passed through the sampling site within hours of hatching.

Larvae of the eleotrid Dormitator latifrons and the sicydiine goby Sicydium punctatum, which share a common morphology with the small undeveloped type of larvae in our study, continued swim-up/sink-down behavior both by day and by night until they developed pigmented eyes (Todd 1975, Bell and Brown 1995). The same behavior was observed in small undeveloped type larvae hatched from egg masses of E. acanthopoma, E. fusca, S. japonicus, S. percnopterygionus, Stenogobius sp., and A. melanocephalus collected from Okinawan streams (our unpubl. data). Therefore, small undeveloped type larvae appear to continue the swim-up/sink-down behavior regardless of light intensity, at least until they develop functional eyes and start feeding.

The spawning nests of gobioid fishes may be dusky even during daytime, because the egg masses are attached mainly to the underside of stones. The spawning nests of $S$. japonicus and $S$. percnopterygionus must be especially dark because they are burrows under stones (Dôtu and Mito 1955; our unpubl. data). If these larvae were to leave the nest in response to lower light intensity, more larvae should occur during daytime because the embryos cannot detect light outside the nest.

After embryonic development in egg capsules under stones, downstream migration of larval gobioids may start after individuals hatch out at dusk, with hatching possibly encouraged by the male parent. Male parents might be able to provoke egg hatching by 
poking or fanning eggs at an optimum time. Eggs of the pipefishes M. leiaspis and M. brachyurus develop in brood pouches attached to the trunk of the male parent (Ishihara and Tachihara 2008), and downstream migration by larvae may begin when the parent releases them at dusk. Nocturnal drifting may prevent decrement by predators.

Due to an artificial perpendicular step located $0.2 \mathrm{~km}$ upstream of the sampling site, adult E. acanthopoma, R. bikolanus, Stenogobius sp., M. leiaspis, and M. brachyurus have never been found in the reaches above the step. The larvae of these fishes must have hatched at dusk within a short reach $(0.2 \mathrm{~km})$ between the sampling site and the step, then drifted down, where we collected them soon after hatching. The other species, E. fusca, S. japonicus, S. percnopterygionus, A. melanocephalus, and Rhinogobius spp., are distributed in the upper reaches up to $1.0 \mathrm{~km}$ or more from the step and may also spawn in the upper reaches. The occurrence of the small undeveloped type and Rhinogobius spp. larvae continued longer (i.e., to around midnight) than $\operatorname{did} R$. bikolanus and pipefish larvae, suggesting that the former included larvae coming down from the upper reaches. However, all larval occurrences ceased after midnight.

Streams on Okinawa Island are generally short and lack gentle courses. The lower reaches of freshwater areas usually have a couple of rapids and pools in each stretch of the stream, and most amphidromous and quasi-amphidromous fishes reside in those areas (Tachihara 2003). Teima Stream represents the typical landscape of a small stream on Okinawa Island. We suggest that the larvae of amphidromous and quasiamphidromous fishes that spawn in freshwater areas in small streams on Okinawa Island usually start drifting soon after hatching at dusk and complete their migration from freshwater into the estuary and sea by midnight.

\section{ACKNOWLEDGMENTS}

We are grateful to those who helped with our $24 \mathrm{hr}$ larval samplings, especially K. Sasaki, T. Ishihara, E. Akane, C. Tajima, and Y. Mizuno
(Faculty of Science, University of the Ryukyus, Japan). We also express our appreciation to two reviewers for comments on the manuscript.

\section{Literature Cited}

Akihito, K. Sakamoto, Y. Ikeda, and K. Sugiyama. 2002. Gobioidei. Pages 11391310 in T. Nakabo, ed. Fishes of Japan with pictorial keys to the species. English ed. Tokai University Press, Tokyo.

Bell, K. N. I. 2007. Opportunities in stream drift: Methods, goby larval types, temporal cycles, in situ mortality estimation, and conservation implications. Bishop Mus. Bull. Cult. Environ. Stud. 3:35-61.

Bell, K. N. I., and J. A. Brown. 1995. Active salinity choice and enhanced swimming endurance in 0 to 8 -d-old larvae of diadromous gobies, including Sicydium punctatum (Pisces), in Dominica, West Indies. Mar. Biol. (Berl.) 121:409-417.

Donaldson, T. J., and R. F. Myers. 2002. Insular freshwater fish faunas of Micronesia: Patterns of species richness and similarity. Environ. Biol. Fishes 65:139-149.

Dôtu, Y., and S. Mito. 1955. Life history of the gobioid fish, Sicydium japonicum Tanaka. Sci. Bull. Fac. Agric. Kyushu Univ. 15:213-221.

Fitzsimons, J. M., J. E. Parham, and R. T. Nishimoto. 2002. Similarities in behavioral ecology among amphidromous and catadromous fishes on the oceanic islands of Hawai'i and Guam. Environ. Biol. Fishes 65:123-129.

Iguchi, K. 2007. Limitations of early seaward migration success in amphidromous fishes. Bishop Mus. Bull. Cult. Environ. Stud. 3:75-85.

Iguchi, K., and N. Mizuno. 1990. Diel changes of larval drift among amphidromous gobies in Japan, especially Rhinogobius brunneus. J. Fish Biol. 37:255-264.

- 1991. Mechanisms of embryonic drift in the amphidromous goby, Rhinogobius brunneus. Environ. Biol. Fishes 31: 295-300.

Ishihara, T., and K. Tachihara. 2008. Reproduction and early development of a 
freshwater pipefish Microphis leiaspis in Okinawa-jima Island, Japan. Ichthyol. Res. 55:349-355.

Keith, P. 2003. Biology and ecology of amphidromous Gobiidae of the Indo-Pacific and the Caribbean regions. J. Fish Biol. 63:831-847.

Luton, C. D., A. M. D. Brasher, D. C. Durkin, and P. Little. 2005. Larval drift of amphidromous shrimp and gobies on the island of Oahu, Hawai'i. Micronesica 38:1-16.

Maeda, K., and K. Tachihara. 2004. Instream distributions and feeding habits of two species of sleeper, Eleotris acanthopoma and E. fusca in the Teima River, Okinawa Island. Ichthyol. Res. 51:233-240.

. 2006. Fish fauna in the Teima Stream, Okinawa Island. Biol. Mag. Okinawa 44:7-25.

Maeda, K., N. Yamasaki, M. Kondo, and K. Tachihara. 2008. Reproductive biology and early development of two species of sleeper, Eleotris acanthopoma and Eleotris fusca (Teleostei: Eleotridae). Pac. Sci. 62:327-340.

Maeda, K., N. Yamasaki, and K. Tachihara. 2007. Size and age at recruitment and spawning season of sleeper, genus Eleotris (Teleostei: Eleotridae) on Okinawa Island, southern Japan. Raffles Bull. Zool. Suppl. 14:199-207.
McDowall, R. M. 1997. Is there such a thing as amphidromy? Micronesica 30:3-14.

Myers, G. S. 1949. Usage of anadromous, catadromous and allied terms for migratory fishes. Copeia 1949:89-97.

Tachihara, K. 2003. The fauna and environment of inland waters in the Ryukyu Islands. Pages 33-41 in M. Nishida, N. Shikatani, and S. Shokita, eds. The flora and fauna of inland waters in the Ryukyu Islands. Tokai University Press, Tokyo.

Takahashi, I., and K. Niimi. 1998. Life history of ayu Plecoglossus altivelis, in the Yahagi River I: Spawning of ayu and downstream migration of their larvae. Rep. Yahagi River Inst. 2:225-245.

Todd, E. S. 1975. Vertical movements and development of the prolarvae of the eleotrid fish, Dormitator latifrons. Copeia 1975: 564-568.

Tomiyama, T., H. Honda, A. Okata, and M. Omori. 1999. Larval drift patterns of diadromous gobies in the lower course of the Natori River, northern Japan. Tohoku J. Agric. Res. 50:11-21.

Yamasaki, N., and K. Tachihara. 2006. Reproductive biology and morphology of eggs and larvae of Stiphodon percnopterygionus (Gobiidae: Sicydiinae) collected from Okinawa Island. Ichthyol. Res. 53:12-18.

- 2007. Eggs and larvae of Awaous melanocephalus (Teleostei: Gobiidae). Ichthyol. Res. 54:89-91. 